\title{
Esktrak ikan haruan (Channa striata) menurunkan jumlah makrofag pada fase inflamasi proses penyembuhan luka (Extract of haruan (Channa striata) decreases macrophages count in inflammation phase of wound healing process)
}

\author{
${ }^{1}$ Putri Sri Hartini, ${ }^{2}$ Nurdiana Dewi, ${ }^{3}$ Lisda Hayatie \\ ${ }^{1}$ Mahasiswa Program Studi Kedokteran Gigi \\ ${ }^{2}$ Bagian Biologi Oral Program Studi Kedokteran Gigi \\ ${ }^{3}$ Bagian Parasit Program Studi Pendidikan Dokter \\ Fakultas Kedokteran Universitas Lambung Mangkurat \\ Banjarmasin, Indonesia
}

\begin{abstract}
Haruan is a kind of freshwater fishes commonly found in South Kalimantan. Haruan extract contains nutritional substances such as albumin, $\mathrm{Zn}, \mathrm{Fe}, \mathrm{Cu}$, and unsaturated fatty acid which can help accelerate wound healing. The aim of this study was to histopathologically assess the effect of $100 \%, 50 \%$, and $25 \%$ haruan extract compared to aquadest and ibuprofen on macrophages count in inflammation phase of wistar rats' buccal mucosa wound healing. This research was a true experimental with post test-only with control design. Samples used were 30 wistar rats divided into 5 groups, 100\%, 50\%, $25 \%$ haruan extract treatment groups, ibuprofen treatment group as positive control, and aquadest treatment group as negative control. Mean macrophages counted on day 3 of 100\%, 50\%, 25\% haruan extract treatment groups aquadest, and ibuprofenl were 2.05, 4.4, 3.9, 3.3, 2.4 respectively. In conclusion, haruan extract had a significant effect in decreasing macrophages count in inflammation phase of wound healing.
\end{abstract}

Keywords: haruan extract, wound healing, inflammation phase, buccal mucosa, wistar rat

\begin{abstract}
ABSTRAK
Ikan haruan merupakan jenis ikan air tawar yang banyak ditemukan di Kalimantan Selatan. Ekstrak ikan haruan memiliki kandungan zat gizi, diantaranya albumin, $\mathrm{Zn}, \mathrm{Fe}, \mathrm{Cu}$, dan asam lemak tak jenuh yang dapat membantu mempercepat penyembuhan luka. Penelitian ini dimaksudkan untuk mengetahui pengaruh pemberian ekstrak ikan haruan 100\%,50\%, dan 25\% secara histopatologi dibandingkan dengan akuades dan ibuprofen terhadap jumlah makrofag pada fase inflamasi penyembuhan luka mukosa bukal tikus wistar.Penelitian eksperimental murni dengan rancangan post test-only with control group, menggunakan tikus wistar sebanyak 30 ekor yang dibagi menjadi 5 kelompok, yaitu kelompok perlakuan ekstrak ikan haruan $100 \%, 50 \%, 25 \%$, kontrol positif yang menggunakan ibuprofen, dan kontrol negatif dengan akuades. Hasilnya menunjukkan rata-rata jumlah makrofag pada hari ke-3 secara berturut-turut pada kelompok ekstrak ikan haruan 100\%, 50\%, 25\%, akuades, dan ibuprofen adalah 2,05; 4,4; 3,9; 3,3; dan 2,4. Disimpulkan bahwa pemberian ekstrak ikan haruan secara bermakna menurunkan jumlah makrofag pada fase inflamasi penyembuhan luka.
\end{abstract}

Kata kunci: ekstrak ikan haruan, penyembuhan luka, fase inflamasi, mukosa bukal, tikus wistar

Koresponden: Putri Sri Hartini, Program Studi Kedokteran Gigi Fakultas Kedokteran Universitas Lambung Mangkurat, Jl. Veteran 128B, Banjarmasin, Kalimantan Selatan.E-mail: putri.hrtn@yahoo.com

\section{PENDAHULUAN}

Hilangnya kontinuitas jaringan yang disebabkan oleh trauma atau prosedur pembedahan didefinisikan sebagai luka. ${ }^{1}$ Trauma iatrogenik adalah luka karena trauma yang disebabkan tindakan serta terapi yang dilakukan dokter gigi atau profesional kesehatan. ${ }^{2}$ Luka yang timbul dalam praktek kedokteran dapat menyebabkan keadaan tidak nyaman bagi pasien dan memudahkan terkena infeksi dan komplikasi lainnya hingga menimbulkan masalah yang lebih berat. Luka padajaringan lunak selanjutnya diikuti dengan proses penyembuhan yang terjadi melalui tiga fase, yaitu fase inflamasi, fase proliferasi, dan fase remodeling. Proses penyembuhan luka dimulai segera setelah terjadinya kerusakan jaringan,meskipun mekanisme dan kecepatan perbaikan jaringan bergantung pada tipe luka.
Beberapa jam setelah luka, terjadilah invasi sel inflamasi pada jaringan luka. Sel polimorfonuklear (PMN) bermigrasi menuju daerah luka dan setelah 24-48 jam sel PMN bertransisi digantikan makrofag yang merupakan sel paling dominan pada inflamasi dengan jumlah paling tinggi pada hari ke-2 sampai hari ke-3. ${ }^{3}$ Makrofag merupakan salah satu sel yang berperan penting dalam respon imun dan fagositosis. Makrofag merupakan monosit yang berada di dalam jaringan, dapat bersatu dan membentuk sel raksasa atau giant cell yang dapat memfagositosis antigen berukuran lebih besar, bahkan mampu memfagosit 100 bakteri. Makrofag juga melepaskan beberapa bahan aktif yang penting untuk proses peradangan dan proses perbaikan luka. Bahan-bahan aktif yang dilepaskan oleh makrofag adalah meliputi plasma dari protein, lalu platelet activating factors (PAF), 
sitokin, faktor-faktor kemotaktik, dan faktor-faktor pertumbuhan. $^{4}$

Inflamasi pada proses penyembuhan luka harus dibatasi. Inflamasi yang terjadi secara terus-menerus dapat menyebabkan proses penyembuhan luka yang tidak normal dan menjadi inflamasi yang patologis. ${ }^{5}$ Obat yang sering digunakan secara sistemik untuk mengurangi gejala inflamasi luka adalah golongan obat anti-inflamasinon-steroid (AINS). Kebanyakan obat golongan ini bersifat asam dan efek yang paling sering terjadi pada pengguna AINS secara oral adalah tukak lambung dan anemia sekunder sebagai akibat perdarahan saluran cerna. ${ }^{6}$

Bahan-bahan alami banyak mendapat perhatian besar pada beberapa dekade terakhir karena dianggap memiliki efek samping yang lebih kecil. ${ }^{7}$ Salah satu bahan alami yang sering digunakan sebagai obat tradisional adalah ikan haruan (Channa striata). ${ }^{8}$ Ekstrakikan haruan secara signifikan meningkatkan kadar albumin dalam kondisi hipoalbuminemia dan mempercepat proses penyembuhan luka. Albumin adalah protein pengangkut utama zat gizi mikro yaitu Zinc ( $\mathrm{Zn})$, sehingga $\mathrm{Zn}$ akan terikat dengan albumin di dalam darah. ${ }^{9}$ Albumin juga berfungsi meregulasi tekanan osmotik, meningkatkan permeabilitas sel, sebagai antioksidan, dan substansi transportasi sel antitrombosis. Ekstrak ikan haruanjuga mengandung $\mathrm{Zn}$ yang berperan dalam mempertahankan sistem imun, mensintesis protein, dan menjaga integritas jaringan ikat serta membatasi kerusakan membran akibat adanya radikal bebas selama peradangan. ${ }^{10}$ Kandungan lainnya yg ditemukan dalam ekstrak ikan haruan adalah besi $(\mathrm{Fe})$, tembaga $(\mathrm{Cu})$, dan asam lemak tak jenuh. ${ }^{11,13}$ Terjadinya defisiensi Fe dan $\mathrm{Zn}$ menyebabkan sirkulasi darah ke jaringan berkurang. ${ }^{9}$

Penelitian ini dilakukan untuk menganalisis pengaruh ekstrak ikan jenis haruan terhadap jumlah makrofag pada fase inflamasi penyembuhan luka mukosa bukal tikus (Rattus norvegicus).

\section{BAHAN DAN METODE}

Sampel penelitian eksperimental murni dengan rancangan post test-only with control group ini ditentukan sampelnya dengan cara simple random sampling. Pembuatan ekstrak dilakukan di Fakultas Matematika dan Ilmu Pengetahuan Alam Universitas Lambung Mangkurat Banjarbaru dan perlakuan pada hewan serta pembuatan preparat histologi dilakukan di Balai Veteriner Banjarbaru.

Hewan coba adalah 30 tikus jantan putih galur Wistar, berat 250-300 gram, umur 2-2,5 bulan. Sampel dibagi menjadi 5 yaitu kelompok perlakuan dengan ekstrak haruan $100 \%$, kelompok perlakuan dengan ekstrakikan haruan 50\%, kelompok perlakuan dengan ekstrak ikan haruan 25\%, kelompok kontrol positif, dan kelompok kontrol negatif,

Sampel ikan haruan diambil di Banjarmasin, Kalimantan Selatan pada bulan Mei 2014.Ikan haruan yang dipilih sebisa mungkin masih dalam keadaan hidup untuk menjaga kualitas ekstraknya. Ikan haruan dibersihkan dari sisik dan darah, kemudian dipotong dan dibuang tulangnya.

Ikan haruan diolah melalui proses pengukusan dengan perbandingan akuades dan ikan haruan 1:1. Akuades dimasukkan terlebih dahulu ke dalam panci kukus kemudian ditutup dengan saringan, selanjutnya ikan haruan dikukus dengan temperatur $70^{\circ} \mathrm{C}$ dengan api sedang selama 50 menit sehingga diperoleh cairan kuning yang dipekatkan menggunakan vaccum rotary evaporator selama $5 \mathrm{jam}$. Ekstrak ikan haruan berupa cairan berwarna kuning muda pekat lalu disaring agar bersih dari kotoran kemudian disimpan dalam wadah. Ibuprofen yang digunakan berbentuk tablet yang digerus kemudian dicampur dengan akuades.

Sampel tikus putih diadaptasikan terlebih dahulu selama satu minggu dalam suasana laboratorium. Tikus putih diambil dan dilakukan pengukuran pada bagian mukosa bukal untukmembuat perlukaan, lalu dilakukan tindakan sedatif dengan menggunakan kapas yang diberi dietil eter. Sayatan dibuat sepanjang $1 \mathrm{~cm}$ dan kedalaman $1 \mathrm{~mm}$ pada bagian mukosa bukal tikus dengan menggunakan scalpel dan blade steril. Tikus dibagi menjadi 15 kelompok secara acak dan diberikan obat secara intraoral dengan dosis ekstrak ikan haruanadalah $10 \mathrm{mg} / \mathrm{kgBB}$ dan dosis ibuprofen adalah $20 \mathrm{mg} / \mathrm{kgBB}$. Dekapitasi sampel dilakukan pada hari ke-1, 3, dan 5. Setelah itu dibuat preparat histologi dari jaringan mukosa bukal yang sudah diambil kemudian dilakukan pewarnaan hematoksilin eosin (HE).

Makrofag diamati dengan mikroskop perbesaran 400x pada 5 lapang pandang. Data yang didapat dari pengamatan diuji normalitas dengan Shapiro Wilk dan dianalisis dengan menggunakan uji Anova 2jalur dan dilanjutkan dengan uji post hoc LSD.

\section{HASIL}

Berdasarkan hasil peneltian, diperoleh grafik ratarata jumlah makrofag kelompok perlakuan (ekstrak ikan haruan $25 \%, 50 \%$, dan $100 \%$ ), kontrol negatif (akuades) dan kontrol positif (ibuprofen) pada hari ke-1, ke-3, dan ke-5.

Pada gambar 1, tampak jumlah makrofag pada kelompok perlakuan ekstrak ikan haruan 100\%, 50\%, $25 \%$, ibuprofen, dan akuades meningkat pada hari pertama.

Pada hari ketiga terjadilah penurunan jumlah makrofag pada tiap kelompok perlakuan. Pada hari 


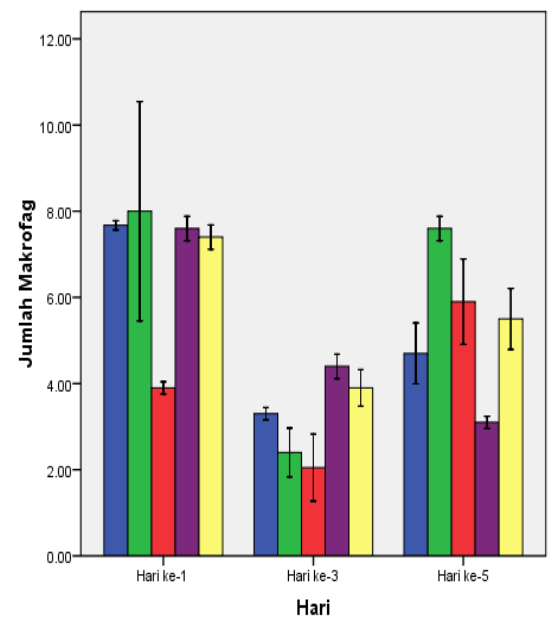

Gambar 1 Grafik rerata jumlah makrofag

hari ke-5 jumlah makrofag pada kelompok perlakuan ekstrak ikan haruan 50\% terus menurun sedangkan jumlah makrofag pada kelompok perlakuan ekstrak ikanharuan $100 \%, 25 \%$,ibuprofen danakuades malah meningkat. Penurunan jumlah makrofag hari ke-5 pada kelompok perlakuan ekstrak ikan haruan 50\% ditandai dengan diagram batang berwarna ungu.

Setelah proses tabulasi data selesai, dilakukan uji normalitas Shapiro-Wilk dengan jumlah sampel kurang dari 50 sampel; pada kelompok hari, yaitu hari ke-1, 3, dan 5 didapatkan data terdistribusi normal dengan nilai $\mathrm{p}=0,165, \mathrm{p}=0,861$, dan $\mathrm{p}=0,741$. Pada kelompok perlakuan, yaitu akuades, ekstrak haruan $100 \%, 50 \%, 25 \%$, akuades, dan ibuprofen didapatkan data terdistribusi normal dengan nilai $\mathrm{p}=0,979, \mathrm{p}=$ $0,172, p=0,807, p=181$, dan $p=0,558$. Semua data dinyatakan normal $(\mathrm{p}>0,05)$ kemudian dilakukan uji homogenitas varians Levene's. Dari hasil perhitungan didapatkan bahwa kelompok hari memiliki nilai signifikansi $0,057(\mathrm{p}>0,05)$ dan kelompok perlakuan memiliki nilai signifikansi $0,429(\mathrm{p}>0,05)$. Hasil tersebut menunjukan bahwa data hasil penghitungan jumlah makrofag memiliki varian yang homogen.

Data tersebut kemudian dilanjutkan dengan uji parametrik Anova 2-jalur, yang menunjukkan bahwa uji perbedaan nyata jumlah makrofag berdasarkan perlakuan memiliki nilai signifikansi $0,007(p<0,05)$ yang berarti bahwajumlah makrofag pada perlakuan menunjukkan perbedaan yang bermakna. Sedangkan uji perbedaan jumlah makrofag berdasarkan hari didapatkan nilai signifikansi $0,001(\mathrm{p}<0,05)$ yang berarti terdapat interaksi antara macam perlakuan dengan hari pengamatan yang menyebabkan jumlah makrofag berbeda signifikan pada taraf kepercayaan $95 \%$.

Selanjutnya dilakukan uji post hoc LSD, pada hari ke-1 menunjukkan terdapat perbedaan bermakna antara kelompok perlakuan akuades dan ekstrak ikan haruan $100 \%$ yang nilai $\mathrm{p}=0,022(\mathrm{p}<0,05)$, kelompok perlakuan ibuprofen dan esktrak ikan haruan 100\% dengan nilai $\mathrm{p}=0,016(\mathrm{p}<0,05)$, ektrak ikan haruan $100 \%$, dan kelompok ekstrak ikan haruan $50 \%$ yang nilai $\mathrm{p}=0,024(\mathrm{p}<0,05)$, kelompok ekstrak ikan haruan $100 \%$ dan kelompok ikan haruan $25 \%$ dengan nilai $\mathrm{p}=0,029(\mathrm{p}<0,05)$.

Tabel 1 Hasil uji post hoc LSD hari pertama

\begin{tabular}{clc}
\hline \multicolumn{2}{c}{ Perlakuan } & Kemaknaan \\
\hline & Akuades & 0,022 \\
\multirow{3}{*}{$100 \%$} & Ibuprofen & 0,016 \\
& $50 \%$ & 0,024 \\
& $25 \%$ & 0,029 \\
\hline \multirow{2}{*}{$50 \%$} & Akuades & 0,951 \\
& Ibuprofen & 0,743 \\
& $25 \%$ & 0,869 \\
\hline \multirow{2}{*}{$25 \%$} & Akuades & 0,821 \\
& Ibuprofen & 0,626 \\
\hline Akuades & Ibuprofen & 0,790 \\
\hline
\end{tabular}

Uji post hoc LSD pada hari ke-3 menunjukkan hasil bahwa terdapat perbedaan bermakna antara kelompok ibuprofen dan kelompok ikan haruan 50\% dengan nilai $\mathrm{p}=0,010(\mathrm{p}<0,05)$, kelompok ibuprofen dan kelompok ekstrak ikan haruan $25 \%$ dengan nilai $\mathrm{p}=0,028 \quad(\mathrm{p}<0,05)$, kelompok ekstrak ikan haruan 100\% dan kelompokekstrak ikan haruan 50\% dengan nilai $\mathrm{p}=0,005(\mathrm{p}<0,05)$, kelompok ekstrak ikan haruan $100 \%$ dan kelompokekstrak ikan haruan $25 \%$ dengan nilai $\mathrm{p}=0,013(\mathrm{p}<0,05)$.

Tabel 2 Hasil uji post hoc LSD hari ketiga

\begin{tabular}{clc}
\hline \multicolumn{2}{c}{ Perlakuan } & Kemaknaan \\
\hline $100 \%$ & Akuades & 0,052 \\
& Ibuprofen & 0,508 \\
& $50 \%$ & 0,005 \\
& $25 \%$ & 0,013 \\
\hline $50 \%$ & Akuades & 0,075 \\
& Ibuprofen & 0,010 \\
& $25 \%$ & 0,355 \\
\hline $25 \%$ & Akuades & 0,276 \\
& Ibuprofen & 0,028 \\
\hline Akuades & Ibuprofen & 0,126 \\
\hline
\end{tabular}

Uji post hoc LSD pada hari ke-5 menunjukkan hasil bahwa terdapat perbedaan bermakna antara kelompok akuades dan kelompok ibuprofen dengan nilai $p=0,006(p<0,05)$, kelompok ibuprofen serta kelompok ekstrak ikan haruan $50 \%$ dengan nilai $\mathrm{p}=$ $0,001(\mathrm{p}<0,05)$, kelompok ibuprofen dan kelompok ekstrak dari ikan haruan $25 \%$ dengan nilai $\mathrm{p}=0,023$ $(\mathrm{p}<0,05)$, kelompok ekstrak ikan haruan 100\% dan kelompok ibuprofen dengan nilai $\mathrm{p}=0,046(\mathrm{p}<0,05)$, kelompok ekstrak ikan haruan 100\% dan kelompok ikan haruan 50\% dengan nilai $\mathrm{p}=0,007 \quad(\mathrm{p}<0,05)$, 
kelompok ekstrak ikan haruan 50\% dan kelompok ekstrak dari ikan haruan $25 \%$ dengan nilai $\mathrm{p}=0,014$ $(\mathrm{p}<0,05)$.

Tabel 3 Hasil uji post hoc LSD hari kelima

\begin{tabular}{|c|c|c|}
\hline \multicolumn{2}{|c|}{ Perlakuan } & Kemaknaan \\
\hline \multirow{4}{*}{$100 \%$} & Akuades & 0,122 \\
\hline & Ibuprofen & 0,046 \\
\hline & $50 \%$ & 0,007 \\
\hline & $25 \%$ & 0,562 \\
\hline \multirow{3}{*}{$50 \%$} & Akuades & 0,056 \\
\hline & Ibuprofen & 0,001 \\
\hline & $25 \%$ & 0,014 \\
\hline \multirow{2}{*}{$25 \%$} & Akuades & 0,270 \\
\hline & Ibuprofen & 0,023 \\
\hline Akuades & Ibuprofen & 0,006 \\
\hline
\end{tabular}

\section{PEMBAHASAN}

Pada penelitian yang dilakukan, pada hari ke-1 telah terjadi peningkatan jumlah makrofag. Hal ini disebabkan pada saat jaringan mengalami kerusakan maka akan terjadi invasi makrofag ke daerah luka. Sesaat setelah terjadinya luka pada mukosa bukal Tikus wistar, terjadi penyembuhan yang diawali dengan terbentuknya bekuan darah pada permukaan luka. Beberapa jam setelah luka, terjadi invasi sel inflamasi pada jaringan luka. Sel polimorfonuklear (PMN) bermigrasi menuju daerah luka dan setelah 24-48 jam terjadi transisi sel PMN menjadi makrofag yang merupakan sel paling dominan pada fase ini selama 5 hari dengan jumlah paling tinggi pada hari ke-2 sampai hari ke-3. ${ }^{2}$

Peningkatan jumlah makrofag pada hari ke-1 dikarenakan terjadinya filtrasi sel radang ke daerah luka, makrofag menjadi aktif danjumlahnya berlipat ganda bila terjadi peradangan. Setelah 2-3 hari usia luka, terjadi pembentukan jaringan granulasi. Secara histologis, terbentuknya jaringan granulasi ditandai dengan proliferasi fibroblas dan kapiler baru yang halus dan berdinding tipis. Selama penyembuhan luka, fibroblas akan aktif bergerak dari jaringan sekitar luka ke dalam daerah luka, kemudian akan berkembang atau berproliferasi serta mengeluarkan beberapa substansi, yaitu kolagen, elastin, fibronektin, hyaluronic acid, fibronektin, dan proteoglycans) yang berperan dalam rekontruksi jaringan baru. ${ }^{18,20}$

Padahari ke-3 jumlah makrofag terus menurun pada masing-masing kelompok perlakuan, tertinggi terjadi pada kelompok perlakuan ekstrak ikan haruan $50 \%$ yang mungkin disebabkan kandungan zat aktif yang dimiliki oleh ekstrak ikan haruan yang lebih banyak dan berguna untuk menghambat vasodilatasi pembuluh darah sehingga makrofag yang migrasi ke dalam jaringan lebih sedikit pada saat fase inflamasi penyembuhan luka. Hal ini mendukung teori yang menyebutkan bahwa ekstrak ikan haruan memiliki efek anti-inflamasi. Berdasarkan hasil pemeriksaan uji kandungan ekstrak ikan haruan $100 \%$ yang sudah dilakukan, diperoleh kandungan albumin $7,568 \mathrm{mg} / \mathrm{L}$, $\mathrm{Zn} 6,70 \mathrm{mg} / \mathrm{L}$, Fe $0,72 \mathrm{mg} / \mathrm{L}$, dan $\mathrm{Cu} 0,447 \mathrm{mg} / \mathrm{L}$.

Albumin merupakan sumber antioksidan hewani yang berfungsi sebagai pengikat radikal sehingga memegang peran dalam proses pembersihan dan penangkapan ROS.Zinc membantu metabolisme dan sekresi insulin, serta melindungi efek kerusakan pankreas. ${ }^{7,20}$ Sedangkan asam lemak tak jenuh yang terdapat pada ikan haruan dapat membantu regulasi sintesis prostaglandin yang penting perannya dalam fase inflamasi danmenginduksi penyembuhan luka. ${ }^{16}$

Zinc berperanan dalam mempercepat proses penyembuhan luka dengan mengurangi peradangan dan menstimulasi re-epitelisasi. Tembaga dan $\mathrm{Fe}$ yang terkandung dalam ekstrak ikan haruan juga merupakan senyawayang membantu sintesis kolagen dan proliferasi. Jika terjadi defisiensi zinc disertai tembaga, mengakibatkan menurunnya kemampuan fagositosis pada sistem imun, terjadinya gangguan penghancuran mikroba dan terganggunya proses penyembuhan luka dan aktivitas mikroba sel fagosit. Sedangkan defisiensi Fe dapat menyebabkan anemia yang menimbulkan berkurangnya pasokan darah dan oksigen ke daerahluka serta menurunnya kemampuan sel radang untuk memfagositosis bakteri sehingga proses penyembuhan luka terganggu. ${ }^{18}$ Hal tersebut yang membuat ekstrak ikan haruan memiliki pengaruh dalam proses penyembuhan luka mukosa bukaltikus wistar, sebab sesuai dengan hasil penelitian bahwa ada penurunan rata-rata jumlah makrofag pada hari ke-1,3, dan 5 pada kelompokesktrak ikan haruan $50 \%$.

Ekstrak ikan haruan konsentrasi $25 \%, 50 \%$, dan $100 \%$ dibandingkan dengan kontrol negatif dan kontrol positif terdapat perbedaan bermakna. Hal ini menunjukkan bahwa ekstrak ikan haruan 25\%, 50\% serta $100 \%$ dapat membantu mempercepat proses penyembuhan luka. Dari penelitian ini disimpulkan bahwa ekstrak ikan haruan konsentrasi 50\% lebih efektifmembantu penurunanjumlah makrofag dalam mempercepat tahap inflamasi proses penyembuhan luka mukosa bukal tikus wistar bila dibandingkan dengan ekstrak ikan haruan $25 \%$ dan $100 \%$, maupun kontrol negatif dan kontrol positif.

\section{DAFTAR PUSTAKA}

1. Sulastri. Hubungan kadar hemoglobin dengan penyembuhan luka post sectio caesarea(SC) di Ruang Mawar I RSUD dr. Moewardi Surakarta. Gaster 2011; 8(2): 772-82 
2. Ozcelik O, Haytac MC, Akkaya M. Iatrogenic trauma of oral tissue. J Periodontol 2005; 76(10):

3. Sugiaman VK. Peningkatan penyembuhan luka di mukosa oral melalui pemberian Aloe Vera (Linn.) secara topikal. JKM 2011; 11:1

4. Febram B, Wientarsih I, Pontjo P. Aktivitas sediaan salep ekstrak batang pohon pisang ambon (Musa paradisiaca var sapientum) dalam proses penyembuhan luka pada mencit (Mus musculus albinus). Majalah Obat Tradisional 2010; 15(3): 121

5. Masir O, Manjas M, Putra AE. Pengaruh cairan cultur filtrate fibroblast (CFF) terhadap penyembuhan luka; penelitian eksperimental pada Rattus norvegicus galur wistar. Jurnal Kesehatan Andalas 2012; 1(3)

6. Ekaputra E. Evolusi menajemen luka. Jakarta: ETN; 2013. p.

7. Arijani E, Christian K. The use of $90 \%$ Aloe vera freeze drying as the modulator of colagen extraction socket of incisivus Cavia cobaya. J Universitas Airlangga 2008: 41(2):

8. Shafri M, Manan A. Therapeutic potential of the haruan (Channa striatus): from food to medicinal uses. Mal J Nutr 2012; 18(1): 125-36

9. Fahmi. Beberapa jenis ikan pemangsa di tambak tradisional dan cara penanganannya. Oseana 2000; 25(1): 21-30

10. Mustafa A, Widodo MA, Kristianto Y. Albumin and zinc content of sneakhead fish (Channa striata) extract and its role in health. Int J Sci Technol 2012; 2(1): 1-8

11. Steen M. Perineal tears and episiotomy: how do wound heal? Br J Midwifery 2007; 15(5): 273-9

12. Sura GM. Efektivitas ekstrak ikan haruan (Channa striata) $100 \%$ padda proses penyembuhan luka kulit punggung mencit (Mus musculus) secara gambaran histopatologi [Skripsi]. Banjarmasin: Fakultas Kedokteran Unlam; 2013.p.

13. Suhartono E, Triawanti, Ari Y, Rizky TF, Iskandar. Chronic cadmium hepatooxidative in rats: treatment with haruan fish (Channa striata). J Sci Direct 2013; 5: 441-5

14. Santoso AH. Uji hipotensi ikan haruan (Channa striata) sebagai hepatoprotektor pada tikus yang diinduksi paracetamol [Tesis]. Bogor: Institut Pertanian Bogor; 2009. p.1-3

15. Wuriani, Suriadi, Priyono D. Uji efektivitas antara penggunaan vitamin C tropikal dan penggunaan vitamin E lokal dalam proses penyembuhan luka untuk tikus. Media Sains 2011;3(1): 63-6

16. Sulistiawati IDAN. Pemberian ekstrak daun lidah buaya (Aloe vera) konsentrasi $75 \%$ lebih menurunkan jumlah makrofag daripada konsentrasi $50 \%$ dan $25 \%$ pada radang mukosa mulut tikus putih jantan [Tesis]. Denpasar: Universitas Udayana; 2011. p

17. Raharjo RA. Perbedaan tingkat penyembuhan luka tikus wistar antara luka yang dibalut dengan kassa tulle dan yang dibalut dengan polyurethane foam. Skripsi. Semarang: Universitas Diponegoro. 2011

18. Fitria M, Saputra D, Revilla G. Pengaruh papain getah pepaya terhadap pembentukan jaringan granulasi pada penyembuhan luka bakar tikus percobaan. Jurnal Kesehatan Andalas. 2014; 3(1): 73-76

19. Soemardini, Pemaningtyas K, Chandra D. Pengaruh pemberian ekstrak ikan gabus (Channa striata) terhadap kadar nitric oxide pada tikus Rattus norvegicus jantan strain wistar model diabetes melitus. Malang: Univeristas Brawijaya. 2012

20.Djokja RM, Lampus BS, Mintjelungan C. Gambaran perokok dan angka kejadian lesi mukosa mulut di desa monsongan kecamatan banggai tengah. Jurnal e-Gigi (eG). 2013; 1(1): 38-44

21. Gosal F, Paringkoan B, Wenas NT. Patofisiologi dan penanganan gastropati obat antiinflamasi nonsteroid. J Indon Med Assoc. 2012; 62(11): 444-449

22. Arianto A. Pembuatan kapsul obat golongan anti-inflamasi nonsteroid (ibuprofen) yang tidak mempunyai efek samping dalam lambung dan pengujian disolusi dan keamanannya terhadap lambung. Jurnal Komunikasi Peneltitian. 2005; 17(5): 49-55

23. Widada W. Pengaruh bekam tehadap peningkatan sel makrofag sebagai sistem kekebalan tubuh. Jurnal Penelitian Kesehatan Suara Forinkes. 2011; 2(3)

24. Harahap S, Jatmiko HD, Harahap MS. Pengaruh sisvastatin terhadap kapasitas fagositosis makrofag pada mencit balb/c yang diberi lipoposakharida. Jurnal Anastesi Indonesia. 2012; 4(2)

25. Setiawan DW, Sulistiyati TD, Suprayitno E. Pemanfaatan residu daging ikan gabus (Ophiocephalus striatus) dalam pembuatan kerupuk ikan beralbumin. THPi Student Journal. 2013; 1(1): 21-32

26. Sjamsuhidajat R, de jong N. Buku ajar ilmu bedah. Jakarta: EGC; 2004. p. 